\title{
Letter to: Endometriosis of the rectosigmoid colon mimicking gastrointestinal stromal tumor
}

\author{
Dg Marshitah Pg Baharuddin (ID), Firdaus Hayati² (D), Nornazirah Azizan³ (ID), Andee Dzulkarmaen Zakaria ${ }^{4}$ (D) \\ ${ }^{1}$ Department of Reproductive Health, Faculty of Medicine and Health Sciences, Universiti Malaysia Sabah, Kota Kinabalu, Sabah, Malaysia \\ 2 Department of Surgery, Faculty of Medicine and Health Sciences, Universiti Malaysia Sabah, Kota Kinabalu, Sabah, Malaysia \\ ${ }^{3}$ Department of Pathobiology and Medical Diagnostic, Faculty of Medicine and Health Sciences, Universiti Malaysia Sabah, Kota Kinabalu, Sabah, Malaysia \\ ${ }^{4}$ Depatment of Surgery, Sains Malaysia University Faculty of Medical Sciences, Kota Bharu, Malaysia
}

Cite this article as: Baharuddin DMP, Hayati F, Azizan N, Zakaria AD. Letter to: Endometriosis of the rectosigmoid colon mimicking gastrointestinal stromal tumor. Turk J Surg 2021 37 (4): 420-421.

\section{Corresponding Author}

\section{Firdaus Hayati}

E-mail: m_firdaus@ums.edu.my

Received: 03.04 .2021

Accepted: 16.08 .202

Available Online Date: 31.12 .2021

O Copyright 2021 by Turkish Surgical Society Available online at www.turkjsurg.com

DOI: 10.47717/turkjsurg.2021.5297
Dear Editor,

We would like to congratulate the authors for publishing such an informative and interesting article (1). We totally agree with the authors to proceed with various modalities and evaluation in this patient who presented with pelvic pain and abdominal bloatedness as it is not easy to diagnose rectosigmoid endometriosis solely by history and physical examination $(2,3)$. However, we believe that there are few issues that can be highlighted in the article to further enhance the visibility of the article value. We value if further detailed gynaecology history could be included namely cyclical pain, dysmenorrhoea, dyschezia and also her fertility status. Physical examination such as tenderness at the pouch of Douglas and thickening of the uterosacral ligament might also give a clue to the preoperative diagnosis of endometriosis as in this patient. In addition, we believe that the readers are keen to know the findings of the transvaginal ultrasound prior to surgical intervention as it has high sensitivity and specificity (4).

The authors stated that the frozen section was performed prior to anterior resection. We were wondering what type of tissue was submitted for the section as intraoperative findings were not described. As we are concerned, gastrointestinal stromal tumor arises from the submucosal tissue, hence we wonder whether the authors performed laparoscopic cytology of the submucosal mass or biopsy of the peritoneal tissues. Commonly, the assessment involved in gastrointestinal pathology of the submucosal lesion is via endoscopic biopsy (5).

In malignant cases, usually, a clinical assessment that shows perforation, bleeding and obstruction warrant a colonic resection or diversion (6). We were wondering about the decision for surgical resection in this case as the reasons were not described in detail. Furthermore, since it is a benign diagnosis following the frozen section, we believe that any lesion above $5-8 \mathrm{~cm}$ from the anal verge as in this case, is better to be managed with conservative management such as hormonal suppression rather than surgical resection to decrease the risk of short- and longterm complications (7).

Lastly, since this is a collaborative effort between general surgery, radiology, obstetrics and gynaecology as well as anatomic pathology until eventual diagnosis, we believe that the involvement of the latter 2 disciplines is crucial as part of the authorship in making this article valuable. In addition, the authors could acknowledge those aforementioned disciplines in the acknowledgement section if they were not involved much in manuscript preparation. We hope that this practice can be improved in the future. 


\section{REFERENCES}

1. Kafadar MT, Çaviş T, Sürgit Ö, Köktener A. Endometriosis of the rectosigmoid colon mimicking gastrointestinal stromal tumor. Turk J Surg 2020; 36(4): 409-12. [CrossRef]

2. Yantiss RK, Clement PB, Young RH. Endometriosis of the intestinal tract: a study of 44 cases of a disease that may cause diverse challenges in clinical and pathologic evaluation. Am J Surg Pathol 2001; 25: 445-54. [CrossRef]

3. Remorgida V, Ferrero S, Fulcheri E, Ragni N, Martin DC. Bowel endometriosis: Preesentation, diagnosis and treatment. Obstet Gynecol Surv 2007; 62(7): 461-70. [CrossRef]

4. Guerriero S, Ajossa S, Orozco R, Perniciano M, Jurado M, Melis GB, et al. Accuracy of transvaginal ultrasound for diagnosis of deep endometriosis in the rectosigmoid: A systematic review and meta-analysis. Ultrasound Obstet Gynecol 2016; 47(3): 281-9. [CrossRef]
5. Zainudin S, Rajanthran SK, Azizan N, Hayati F, Ginawoi J, Suhaimi $K A$, et al. An oncological curiosity of a male patient with a huge leiomyoma of the terminal ileum. Oxf Med Case Reports 2020; 2020(10): omaa086. [CrossRef]

6. Yang XF, Pan K. Diagnosis and management of acute complications in patients with colon cancer: Bleeding, obstruction, and perforation. Chin J Cancer Res 2014; 26(3): 331-40. [CrossRef]

7. Nezhat C, Li A, Falik R, Copeland D, Razavi G, Shakib A, et al. Bowel endometriosis and management. Am J Obstet Gynecol 2018; 218(6): 549-62. [CrossRef] 